\title{
Anti-inflammatory, antinociceptive, and antipyretic effects of methanol extract of Cariniana rubra stem bark in animal models
}

\author{
EDSON N. SANTOS ${ }^{1}$, JOAQUIM C.S. LIMA ${ }^{1}$, VÂNIA F. NOLDIN ${ }^{2}$, VALDIR CECHINEL-FILHO ${ }^{2}$, \\ VIETLA S.N. RAO ${ }^{3}$, EVANGELISTA F. LIMA ${ }^{4}$, GUILLERMO SCHMEDA-HIRSCHMANN ${ }^{5}$, \\ PAULO T. SOUSA $\mathrm{Jr}^{4}$ and DOMINGOS T.O. MARTINS ${ }^{1}$ \\ ${ }^{1}$ Departamento de Ciências Básicas em Saúde, Faculdade de Medicina, Universidade Federal de Mato Grosso \\ Av. Fernando Correa da Costa, 2367, Boa Esperança, Campus Universitário, 78060-900 Cuiabá, MT, Brasil \\ ${ }^{2}$ Centro de Pesquisa Químico-Farmacêutica/NIQFAR, Universidade do Vale do Itajaí \\ Rua Uruguai, 458, 88302-202 Itajaí, SC, Brasil \\ ${ }^{3}$ Departamento de Fisiologia e Farmacologia, Faculdade de Medicina, Universidade Federal de Ceará \\ Rua Cel Nunes de Melo 1127, Porangabussu, 60430-270 Fortaleza, CE, Brasil \\ ${ }^{4}$ Laboratório de Pesquisa em Química de Produtos Naturais/ICET, Universidade Federal de Mato Grosso \\ Av. Fernando Correa da Costa, 2367, Boa Esperança, Campus Universitário, 78060-900 Cuiabá, MT, Brasil \\ ${ }^{5}$ Instituto de Química de Recursos Naturales (IQRN), Universidad de Talca, Casilla: 747, 2 Norte 685, Talca, Chile
}

Manuscript received on October 26, 2009; accepted for publication on August 27, 2010

\begin{abstract}
Cariniana rubra Miers (Lecythidaceae), popularly known as "jequitibá-vermelho", is a large Brazilian tree whose bark is used in infusion and decoction for the treatment of inflammatory conditions. This study aims to assess the anti-inflammatory, antinociceptive, and antipyretic effects of Cariniana rubra methanolic stem bark extract (EMCr) using experimental animals. Anti-inflammatory activity of EMCr was tested on carrageenan and dextran-induced rat paw edema, carrageenan-induced pleurisy in rats and acetic acid-increase vascular permeability in mice. Antinociceptive and antipyretic activities were evaluated using acetic acid-induced writhing, formalin and hot-plate tests in mice, as well as brewer's yeast-induced pyrexia in rats. The extract inhibitied carrageenan and dextran-induced edema, reduced exudate volume and leukocyte migration on the carrageenan-induced pleurisy and on the vascular permeability increase induced by acetic acid. The EMCr inhibited nociception on the acetic acid-induced writhing and in the second phase of formalin test, and decreased rectal temperature. It was, however, inactive against thermal nociception. Phytochemical analysis with EMCr showed the occurrence of saponins, triterpenes, sterols and phenolic compounds. Phytosterols ( $\beta$-sitosterol, stigmasterol), pentacyclic triterpenes ( $\alpha$ - and $\beta$-amyrin as a mixture), arjunolic acid, a phytosterol glycoside (sitosterol 3- $O$ - $\beta$-D-glucopyranoside), and triterpenoid saponins (28- $\beta$-glucopyranosyl-23- $O$-acetyl arjunolic acid; 3- $O$ - $\beta$-glucopyranosyl arjunolic acid and 28- $O$-[ $\alpha$-L-Rhamnopyranosyl- $(1 \rightarrow 2)-\beta$-glucopyranosyl]-23$O$-acetyl arjunolic acid) were the main identified compounds. It can be presumed that EMCr caused their effects by inhibiting the liberation and/or action of different inflammatory mediators. These findings support the traditional use of Cariniana rubra preparations to treat inflammation.
\end{abstract}

Key words: anti-inflammatory, antinociceptive, antipyretic, Cariniana rubra, Lecythidaceae, triterpenoidal saponins.

\section{INTRODUCTION}

Cariniana rubra Miers (Lecythidaceae), popularly known as "jequitibá-vermelho", is a large tree that grows abundantly in the hills and forests of the Brazil-

Correspondence to: Domingos Tabajara de Oliveira Martins

E-mail: taba@terra.com.br ian states of Mato Grosso, Goiás, Tocantins and Minas Gerais States of Brazil. Its stem bark is a reputed traditional remedy in the form of decoctions and infusions for the treatment of inflammatory conditions, especially sore throat, oophoritis and venereal diseases (De La Cruz 2008). 
No scientific reports in support of the traditional use of this plant are available, although phytochemical studies indicated the presence of phenolic compounds in $C$. rubra, such as $\beta$-sitosterol, stigmasterol, $\alpha$ - and $\beta$-amyrins, arjunolic acid, sitosterol 3-O- $\beta$-D-glucopyranoside, the triterpenoidal saponins $28-\beta$-glucopyranosyl-23- $O$-acetyl arjunolic acid; 3- $O-\beta$-glucopyranosyl arjunolic acid and 28- $O$-[ $\alpha$-L-Rhamnopyranosyl- $(1 \rightarrow$ 2)- $\beta$-glucopyranosyl]-23- $O$-acetyl arjunolic acid (Lima et al. 2002).

The traditional knowledge on the medicinal use of plants should be assessed under laboratory conditions using appropriate biological assays to disclose if the traditional claims are evidence-supported. In this context, the ethnopharmacological approach provides specific targets for pharmacological and chemical investigation, looking for a possible development of new plant-derived drugs. With this objective, the present study aims to verify the possible anti-inflammatory, antinociceptive, and antipyretic effects of methanol extract from C. rubra stem bark in selected animal models. In addition, the plant extract was also subjetcted to phytochemical analysis.

\section{MATERIALS AND METHODS}

\section{Plant MATERIAL AND EXTRACTION}

The stem bark of Cariniana rubra was collected in November 1997 by Liberio Amorim Neto, at Serra de São Vicente, Cuiabá Municipality, Mato Grosso State, Brazil. It was identified by Prof. Dr Germano Guarim Neto, Department of Botany and Ecology, Federal University of Mato Grosso, Brazil.

A voucher specimen (\# 18337) was deposited in the Herbarium of the University. The collection was authorized by the Brazilian Institute of Environment and Renewable Natural Resources.

The finely powdered bark of C. rubra $(1 \mathrm{~kg})$ was packed into a Sohxlet extractor and extracted for $48 \mathrm{~h}$, with absolute methanol. The solvent was removed under reduced pressure using a rotavapor to obtain $333 \mathrm{~g}$ (33\%) of a dark brown solid. The dry extract (EMCr) was suspended in distilled water for the pharmacological studies.

\section{Phytochemical ANALYsis}

The air-dried plant material $(150 \mathrm{~g})$ was extracted with methanol:water $(80: 20 \mathrm{v} / \mathrm{v}, 500 \mathrm{~mL})$ in a Soxhlet apparatus to obtain the hydrophilic extract. The lipophilic extract was obtained as above, using diethyl ether $(500 \mathrm{~mL})$ as solvent. The chemical analysis was performed on the hydrophilic and the lipophilic extracts, according to the literature (Matos 1988).

Chromatographic fractionation was carried out using silica gel chromatography and permeation on Sephadex LH-20, as well as by high speed countercurrent chromatography (HSCCC) and medium pressure chromatography. The structure determination of the main compounds was carried out using spectroscopic techniques as previously reported (Harbone 1998, Matos 1988, Lima et al. 2002, E.F. Lima, unpublished data).

\section{ANIMALS}

Male Wistar rats (170-250 g) and male Swiss mice (25-30 g) were used. Experimental groups consisted of 8 animals per group. They were housed at $22 \pm 1^{\circ} \mathrm{C}$ under a $12 \mathrm{~h} \mathrm{light} / 12 \mathrm{~h}$ dark cycle, and had free access to standard pellet diet (Purina ${ }^{\circledR}$ chow) and tap water. The animals were deprived of food for 15-24 h before experimentation, but had free access to drinking water.

The Animal Care and Use Committee of the Universidade Federal do Mato Grosso approved the experimental protocols in accordance with the ethical guidelines for the investigation of experimental pain in conscious animals (Zimmermann 1983).

\section{ANTI-INFLAMMATORY ASSAYS}

\section{Hind paw-edema induced by carrageenan and dextran}

Paw edema was induced in the left hind paw of rats (180-200 g) by sub-plantar injection of $0.1 \mathrm{~mL}$ of $1 \%$ $\lambda$-carrageenan or $1.5 \%$ of dextran $(\mathrm{w} / \mathrm{v})$ in $0.9 \%$ of saline. The paw volume was measured before (0) and $3 \mathrm{~h}$ after carrageenan injection or $2 \mathrm{~h}$ after dextran (Parrat and West 1957) using a plethysmometer (Ugo Basile). The edema was expressed as an increase in paw volume. Different groups of animals were treated by gastric gavage with $\mathrm{EMCr}(250,750$ and $2,000 \mathrm{mg} / \mathrm{kg})$, indomethacin $(5 \mathrm{mg} / \mathrm{kg})$, cyproheptadine $(5 \mathrm{mg} / \mathrm{kg})$ or 
vehicle $(10 \mathrm{~mL} / \mathrm{kg})$ in a volume of $10 \mathrm{~mL} / \mathrm{kg}, 1 \mathrm{~h}$ before carrageenan or dextran injection (Winter et al. 1962).

\section{Carrageenan-induced pleurisy in rats}

Pleurisy was induced in rats (200-220 g) by intrapleural injection of $2 \% \lambda$-carrageenan suspension $(0.1 \mathrm{~mL} / \mathrm{rat})$ in $0.9 \%$ of saline (Vinegar et al. 1978). The EMCr $(250,750,1,500$, and $2,000 \mathrm{mg} / \mathrm{kg})$, dexamethasone $(0.5 \mathrm{mg} / \mathrm{kg})$ or vehicle $(10 \mathrm{~mL} / \mathrm{kg})$ were given by gastric gavage $1 \mathrm{~h}$ before the injection of irritant agent. Six hours after the injection of carrageenan, the rats were killed by excess of ether. The pleural cavity was opened and rinsed with $1 \mathrm{~mL}$ of saline solution containing $0.1 \%$ of EDTA. The exudate and washing solution were collected by aspiration and the total volume measured $(\mathrm{mL})$. The mobilized leukocyte number in the exudate was quantified using improved Neubauer counting chambers.

\section{Acetic acid-induced increase in vascular permeability}

Groups of mice (25-30 g) were treated by gastric gavage with vehicle $(10 \mathrm{~mL} / \mathrm{kg}), \mathrm{EMCr}(50,250$, and $750 \mathrm{mg} / \mathrm{kg})$ or dexamethasone $(0.5 \mathrm{mg} / \mathrm{kg})$ in a volume of $10 \mathrm{~mL} / \mathrm{kg}$. One hour after these treatments, each animal received an intravenous injection of 2\% Evan's blue solution (w/v) in $0.9 \%$ of saline. Ten minutes later, each mouse received intraperitoneally $0.4 \mathrm{~mL}$ of $0.5 \%$ acetic acid solution. Twenty minutes after acetic acid injection, the animals were killed, the peritoneal fluid was collected and the concentration of Evan's blue was measured by absorbance at $590 \mathrm{~nm}$ in a spectrophotometer.

The dye extravasation was quantified from a standard curve and expressed in $\mu \mathrm{g}$ (Whittle 1964).

\section{Antinociceptive Assays}

\section{Writhing test}

Abdominal constriction induced by intraperitoneal injection of acid acetic was carried out according to a method described earlier (Koster et al. 1959). In this test, groups of mice were treated with the vehicle, $\mathrm{EMCr}(50,250$ and $750 \mathrm{mg} / \mathrm{kg})$ or indomethacin $(5 \mathrm{mg} /$ $\mathrm{kg}), 1 \mathrm{~h}$ before the administration of acetic acid $(0.6 \%$, $10 \mathrm{~mL} / \mathrm{kg}$, i.p.). The number of writhings was counted for each animal, starting 10 min after acetic acid injection over a period of $20 \mathrm{~min}$.

\section{Formalin test}

In formalin test, groups of mice were treated by gastric gavage with vehicle or $\operatorname{EMCr}(50,250$, and $750 \mathrm{mg} / \mathrm{kg})$ and, one hour later, each mouse was given $25 \mu \mathrm{L}$ of $2.5 \%$ formalin (in $0.9 \%$ of saline, subplantar) into the left hind paw (Hunskaar and Hole 1987). The duration of paw licking (s) as an index of painful response was determined at 0-5 min (early phase, neurogenic) and 20-25 min (late phase, inflammatory) after formalin injection. Meperidine $(25 \mathrm{mg} / \mathrm{kg}$, s.c., $30 \mathrm{~min}$ before the test) pre-treated animals were included in the study as a positive control.

\section{Hot-plate test}

In thermal nociceptive test, the reaction time (time in seconds elapsed between placement and the animal starting to lick its hind paw or jumping as an index of painful response) in a hotplate maintained at $56 \pm 1^{\circ} \mathrm{C}$ was measured before and after 15, 30, 60, 120, and $180 \mathrm{~min}$ of drug administration (Eddy and Leimbach 1953). Mice with baseline latencies of more than $15 \mathrm{~s}$ were eliminated from the study. Animal groups were treated with the vehicle, $\operatorname{EMCr}(50,250$, and $750 \mathrm{mg} /$ $\mathrm{kg}$ ) or meperidine $(25 \mathrm{mg} / \mathrm{kg}$, s.c.) 60 or $30 \mathrm{~min}$ (in case of meperidine) before the hot-plate test. The cut-off time was set at $45 \mathrm{~s}$.

\section{ANTIPYRETIC ASSAY}

\section{Brewer's yeast induced pyrexia}

Pyrexia was induced in rats (200-220 g) by subcutaneous injection of $10 \mathrm{~mL} / \mathrm{kg}$ of $20 \%$ brewer's yeast suspension (w/v) in $0.9 \%$ of saline (Al-Ghamdi 2001). Twenty-one hours later, the animals were treated by gastric gavage with vehicle, $\mathrm{EMCr}(250,750$, and $2,000 \mathrm{mg} / \mathrm{kg})$ or phenacetin $(175 \mathrm{mg} / \mathrm{kg})$. The rectal temperature of the rats was determined with a digital thermometer. It was inserted $3 \mathrm{~cm}$ into the rectum anus and the temperature measured before and 1, 2, and $3 \mathrm{~h}$ after the treatments. In another group, the animals received a subcutaneous injection from $0.9 \%$ of normal saline $(1 \mathrm{~mL} / 100 \mathrm{~g})$, and $21 \mathrm{~h}$ later received the vehicle 
by gastric gavage. The rectal temperature was determined and included in the study as a negative control.

\section{Statistical analysis}

All parametric values are given as Mean \pm S.E.M and were analyzed by One-way ANOVA followed by Student Newman-Keuls test for significance at $p<0.05$.

\section{RESULTS}

\section{Phytochemical ANALYsis}

The chemical analysis of the methanolic stem bark extract of $C$. rubra (EMCr) showed the presence of saponins, tannins, free steroids, flavonols and flavones. Several constituents were isolated and identified by spectroscopic means, including phytosterols and pentacyclic triterpenoids ( $\beta$-sitosterol, stigmasterol, $\alpha$ and $\beta$-amyrins, arjunolic acid), phenolic compounds, the steroid glycoside sitosterol 3-O- $\beta$-D-glucopyranoside, and triterpenoidal saponins (28- $\beta$-glucopyranosyl-23$O$-acetyl arjunolic acid; 3- $O$ - $\beta$-glucopyranosyl arjunolic acid and 28- $O$-[ $\beta$-L-rhamnopyranosyl- $(1 \rightarrow 2)-\beta$ glucopyranosyl]-23- $O$-acetyl arjunolic acid). The structures are in agreement with literature data and co-chromatography with authentic samples (Lima et al. 2002, E.F. Lima, unpublished data).

\section{ANTI-INFLAMMATORY EVALUATION}

$\mathrm{EMCr}$ was evaluated in the model of rat paw edema induced by carrageenan or dextran. Table I shows that the $\mathrm{EMCr}(750$, and $2,000 \mathrm{mg} / \mathrm{kg})$ and indomethacin $(5 \mathrm{mg} / \mathrm{kg})$ significantly reduced the carrageenan-induced rat hind paw edema by 29 ( $p<0.01), 38$ ( $p<$ $0.001)$ and $55 \%(p<0.001)$, respectively, compared to control values. However, in the dextran-induced paw edema, EMCr was active only at 2,000 $\mathrm{mg} / \mathrm{kg}$ (60 $p<0.001)$. Under the same experimental conditions, cyproheptadine $(5 \mathrm{mg} / \mathrm{kg})$ reduced inflammation by $54 \%(p<0.001)$.

The results on the effect of plant extract on carrageenan pleurisy test are presented in Figure 1. In the present investigation, we compared the effect of the $\mathrm{EMCr}$ at 250, 750, 1,500, and 2,000 mg/kg and dexamethasone on the cell migration. The EMCr at 1,500 and $2,000 \mathrm{mg} / \mathrm{kg}$ markedly inhibited the carrageenan- induced pleuritic exudate by $46(p<0.01)$ and $80 \%$ $(p<0.001)$, and the leukocyte migration by 37 ( $p<$ $0.01)$ and $80 \%(p<0.001)$, respectively. Dexamethasone, the reference drug used in the study, produced $83(p<0.001)$ and 86\% $(p<0.001)$ inhibitions, respectively. The increased vascular permeability caused by intraperitoneal acetic acid was found to be significantly reduced in mice pretreated with 50, 250, and $750 \mathrm{mg} / \mathrm{kg}$ of the plant extract in a dose-dependent manner (Fig. 2).

\section{ANTINOCICEPTIVE EVALUATION}

Figure 3 shows that the mean number of writhes following intraperitoneal administration of $0.6 \%$ acetic acid in vehicle-treated control mice was $44 \pm 1$. Animal groups that received the plant extract at 250, and $750 \mathrm{mg} / \mathrm{kg}$ or indomethacin $(5 \mathrm{mg} / \mathrm{kg})$ demonstrated significantly diminished number of writhes (12, 57 $p<0.01$ and $70 \%-p<0.01$, respectively).

In the formalin test, vehicle-treated animals showed the mean licking times (s) of $81 \pm 4$ in the first phase, and $173 \pm 12$ in the second phase (Fig. 4). Pretreatment with the $\mathrm{EMCr}$ at $750 \mathrm{mg} / \mathrm{kg}$ did not show significant effect on the first phase response, but significantly diminished the second phase (inflammatory pain) response by $28 \%(p<0.01)$. However, meperidine (25 mg/kg, s.c), a known analgesic, produced marked inhibition at both phases $(84-p<0.001$ and $99 \%-p<0.001$, respectively).

The present study indicates that, unlike meperidine (25 mg/kg, s.c.), the EMCr $(50,250$, and $750 \mathrm{mg} / \mathrm{kg})$ failed to show any significant analgesia in the hot-plate test (data not shown).

\section{ANTIPYRETIC EVALUATION}

The subcutaneous injection of brewer's yeast suspension $20 \%$ increased considerably the rectal temperature of the rats $21 \mathrm{~h}$ after administration $\left(38.3 \pm 0.13^{\circ} \mathrm{C} v s\right.$. $\left.37.1 \pm 0.16^{\circ} \mathrm{C}, p<0.001\right)$. The EMCr treatment, with 750 and $2,000 \mathrm{mg} / \mathrm{kg}$, significantly reduced the rectal temperature of the animals in the second and third $h$ after administration, reaching the peak of antipyretic effect with the highest dose in the second $\mathrm{h}$ (37.5 \pm $\left.0.08^{\circ} \mathrm{C}, p<0.001\right)$, in relation to control (38.5 \pm $\left.0.01^{\circ} \mathrm{C}\right)$. The phenacetin treatment $(30 \mathrm{mg} / \mathrm{kg})$ caused 
TABLE I

Effect of methanol extract of Cariniana rubra stem bark (EMCr)

on carrageenan and dextran-induced hind paw edema in rats.

\begin{tabular}{l|c|c|c}
\hline \multirow{2}{*}{ Treatment } & \multirow{2}{*}{$\begin{array}{c}\text { Dosage } \\
\text { (mg/kg, p.o) }\end{array}$} & $\begin{array}{c}\mid c \\
\text { carrageenan }\end{array}$ & $\begin{array}{c}\text { Paw edema }(\mathrm{mL}) \\
\text { dextran }\end{array}$ \\
\cline { 3 - 4 } & & $1.07 \pm 0.03$ & $0.65 \pm 0.07$ \\
Control (vehicle) & & $0.94 \pm 0.04$ & $0.58 \pm 0.04$ \\
EMCr & 250 & $0.76 \pm 0.09^{* *}$ & $0.49 \pm 0.05$ \\
& 750 & $0.66 \pm 0.05^{* * *}$ & $0.26 \pm 0.06^{* * *}$ \\
Indomethacin & 2000 & $0.48 \pm 0.02^{* * *}$ & - \\
Cyproheptadine & 5 & - & $0.30 \pm 0.05^{* * *}$ \\
\hline
\end{tabular}

Each value represents mean \pm S.E.M. of 8 animals. ${ }^{* *} p<0.01 ; * * * p<$ 0.001. One-way ANOVA was followed by Student-Newman-Keuls.
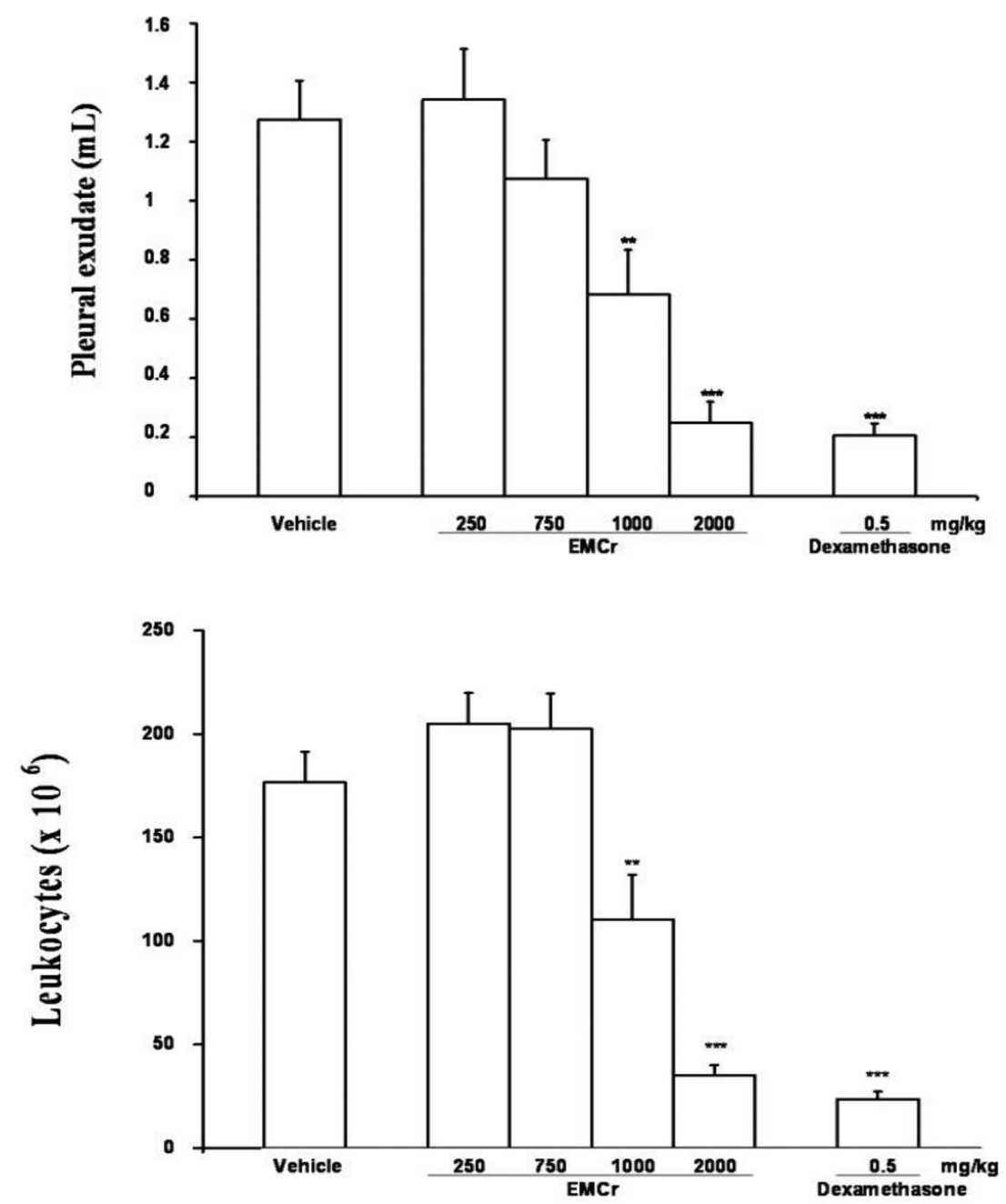

Fig. 1 - Effect of oral administration of Cariniana rubra methanol extract (EMCr) or dexamethasone on exudate volume and leukocyte numbers $\left(\times 10^{6}\right)$ in a $6 \mathrm{~h}$ rat carrageenan pleurisy test. Value represents mean \pm S.E.M. for 8 animals. $* * p<0.01 ; * * * p<0.001$ One-way ANOVA was followed by Student-Newman-Keuls. 


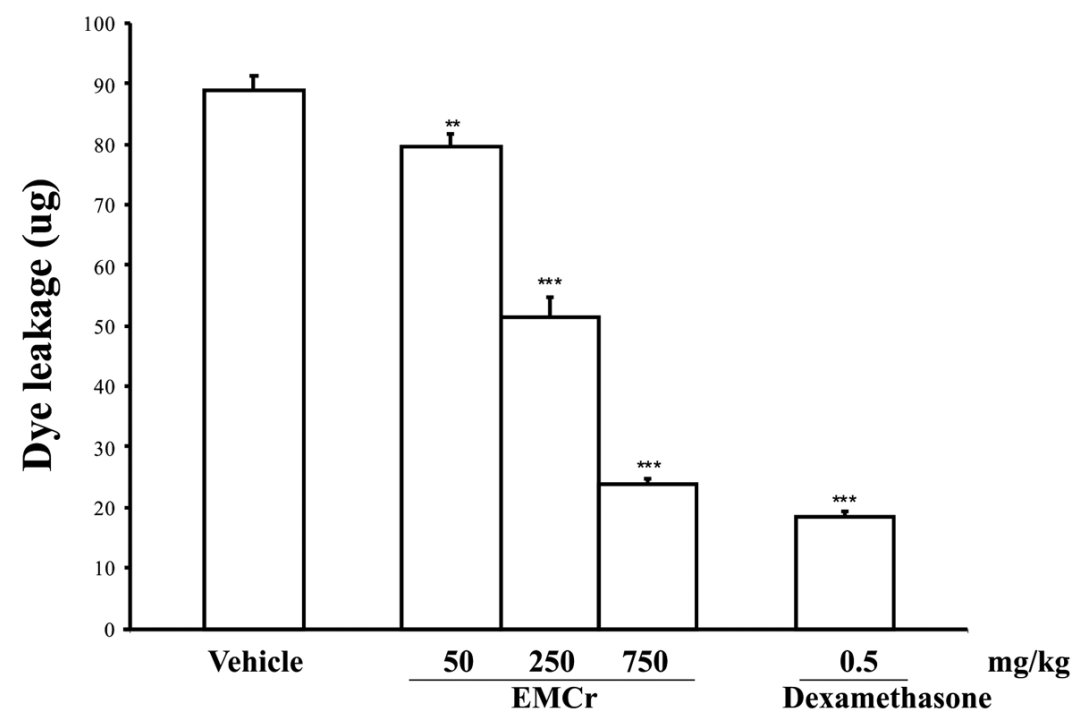

Fig. 2 - Effect of methanol extract from Cariniana rubra and dexamethasone on acetic acid-induced increase in vascular permeability in mice. Value represents mean \pm S.E.M. for 8 animals. ${ }^{* *} p<0.01,{ }^{* * *} p<0.001$. One-way ANOVA was followed by Student-Newman-Keuls.

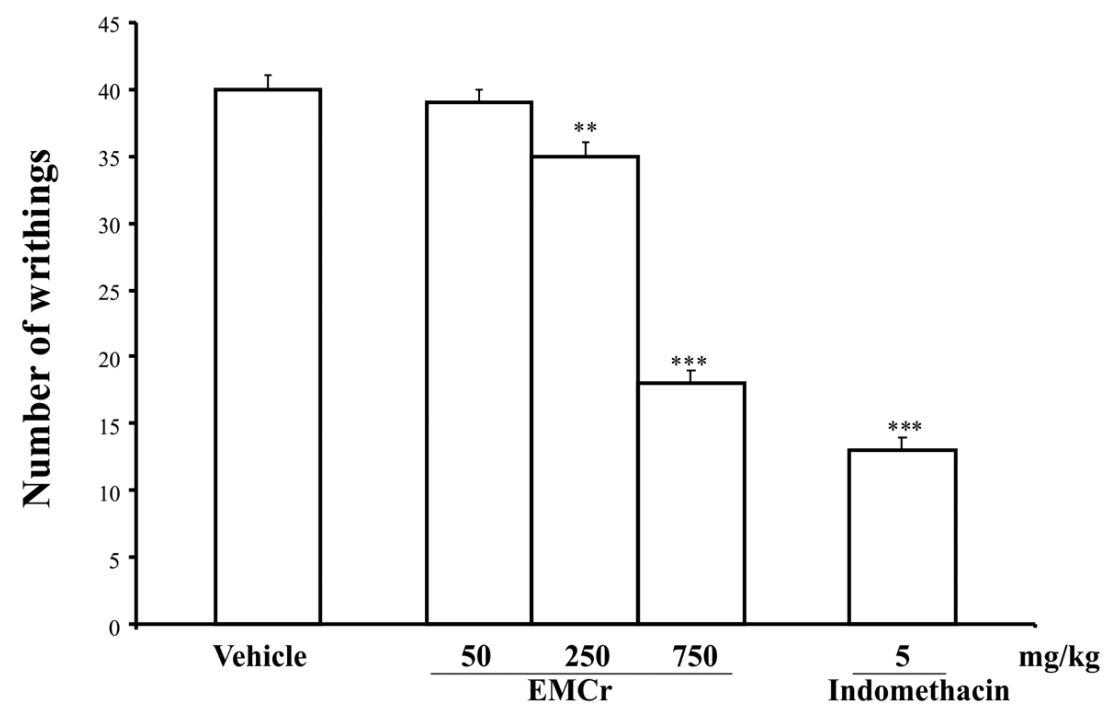

Fig. 3 - Effect of methanol extract of Cariniana rubra (EMCr) against acetic acid-induced abdominal constriction in mice. Value represents mean \pm S.E.M. Each point represents the mean \pm S.E.M. of 8 animals. ${ }^{*} p<0.05 ; * * p<0.01 ; * * *<0.001$. One-way ANOVA was followed by Student-Newman-Keuls.

significant antipyretic effect at all time periods, reaching the peak in the second $\mathrm{h}\left(37.0 \pm 0.09^{\circ} \mathrm{C}, p<0.001\right)$, in relation to control $\left(38.3 \pm 0.08^{\circ} \mathrm{C}\right)$ (Fig. 5).

\section{DISCUSSION}

Natural products of plant origin are used in folk medicine all over the word. They exhibit a wide range of pharmacological activities and may provide relief of symptoms often comparable to that obtained from allo- pathic medicines. The results reached in this study suggest that EMCr possesses anti-inflammatory, antinociceptive and antipyretic properties and support the traditional use of this plant to treat inflammatory conditions. In rats and mice, oral administration of $\mathrm{EMCr}$ reduced the carrageenan and dextran-induced edema. It has been referred that, after the carrageenan injection on the rat's paw, several mediators are released sequentially like histamine, serotonin and bradykinin in the 


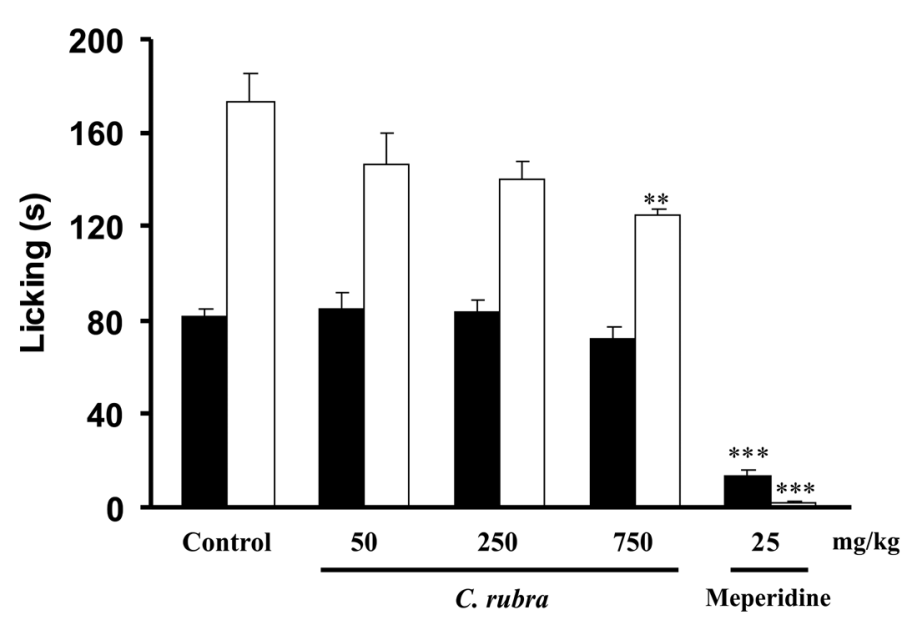

Fig. 4 - Effect of vehicle or methanol extract from Cariniana rubra (EMCr) and meperidine on formalin-induced nociception in mice. Each column represents mean \pm S.E.M. of 8 animals. ${ }^{* *} p<0.01, * * * p<0.001$. One-way ANOVA was followed by Student-Newman-Keuls.

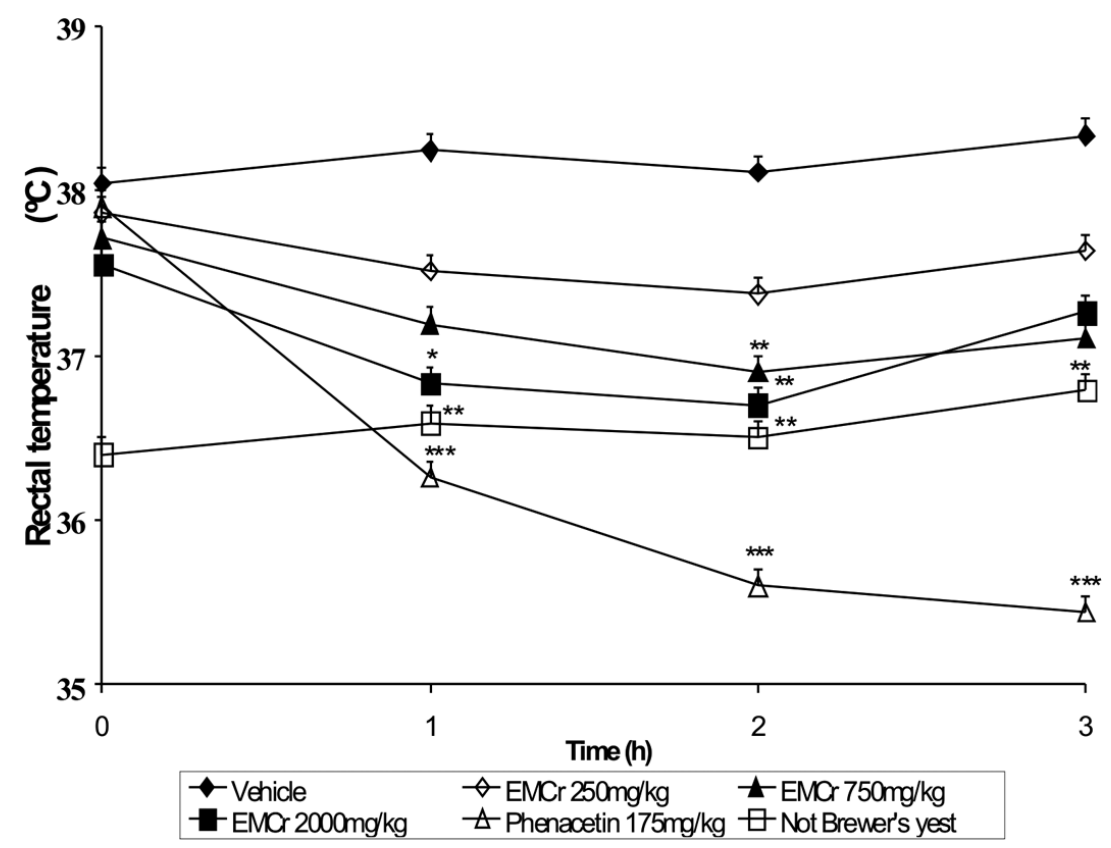

Fig. 5 - Effect of vehicle, methanol extract of Cariniana rubra (EMCr) or phenacetin on Brewer's yeast-induced hyperthermia in rats. Each point represents the mean \pm S.E.M. of 8 animals. ${ }^{*} p<$ $0.05 ; * * p<0.01 ; * * *<0.001$. One-way ANOVA was followed by Student-Newman-Keuls.

initial phase $(0-1 \mathrm{~h})$, and an increase in the production of prostaglandins through the activation of cyclooxygenase- 2 and release of nitric oxide in the later phase (1-6 h) are reported (Silva et al. 2005). It is likely that the extract might have suppressed the edema formation by the inhibition of the inflammatory mediator substances. In addition, the extract effectively reduced the vascular permeability in intraperitoneal acetic acid test wherein many components of inflammatory cascade participate involving resident cells, macrophages and mast 
cells (Whittle 1964, Ribeiro et al. 2000). The increase in vascular permeability induced by acetic acid is known to correspond to the initial exudative inflammation and, conversely, its inhibition may contribute to the reduction of edema formation and to decrease the migration of neutrophils. Histamine and serotonin are the principal mediators involved in the dextran-induced paw edema, and their release is a result of mast cell degranulation (Lo et al. 1982). EMCr effectively suppressed the dextran edema, and its effect at $750 \mathrm{mg} / \mathrm{kg}$ was similar to that of $0.5 \mathrm{mg} / \mathrm{kg}$ dexamethasone.

The injection of carrageenan into the pleural cavity of rodents provokes an acute inflammatory response characterized by the accumulation of fluids in the pleural cavity with a large number of polymorphonuclear leukocytes. This eventually leads to the increased levels of prostaglandin $E_{2}$, reactive oxygen intermediates, lipid peroxidation, and cytokines such as TNF- $\alpha$ and IL- $1 \beta$ (Di Paola et al. 2004). Cell migration occurs as a result of different processes including adhesion and cell mobility (Meade et al. 1986). The extract treated animals displayed less neutrophils in the pleural cavity fluids than in the controls, suggesting the inhibition of neutrophil influx.

Besides anti-inflammatory activity, the EMCr demonstrated antinociceptive activity in the experimental models of chemical nociception induced by acetic acid and in the second phase of subplantar formalin. However, it was inactive in the first phase of formalin and in hot-plate tests, suggesting that the effect of EMCr is related to the anti-inflammatory action.

The acetic acid-induced abdominal writhing test is a visceral pain model commonly used to assess the inflammatory pain for its high sensitivity, despite its low specificity. Acetic acid unleashes the release of several mediators such as bradykinin, substance $\mathrm{P}$ and prostaglandins, as well as cytokines such as IL- $1 \beta, \mathrm{TNF} \alpha$ and IL-8 (Sekiya 1982). The antinociceptive activity demonstrated by $\mathrm{EMCr}$ in this model implies that it is likely to inhibit these mediators and, thus, the activation of chemosensitive nociceptors that contribute to the development of inflammatory pain.

The formalin test is more specific and simulate clinical pain. Several reports suggest that formalin-induced licking response is mediated by the release of the excitatory amino acid glutamate at the first phase, and by sensory neuropeptides like substance P released from sensory neurons at the spinal cord at the second phase (Otuki et al. 2001). Since EMCr failed to show antinociception in the first phase of formalin test, possibly EMCr has only peripheral antinociceptive activity.

Most of non-steroidal anti-inflammatory drugs (NSAIDs) exert antipyretic effects inhibiting prostaglandins production (Dinarello 1989), thereby suppressing inflammation-associated hyperthermia (Kaufmann et al. 1997). The injection of brewer's yeast causes the liberation of proinflammatory cytokines and stimulates the synthesis of prostaglandin $E_{2}$ in the surroundings of the hypothalamic thermoregulator centers (Chan and Fiscus 2004). Since the extract manifests a significant antipyretic effect in yeast-induced pyrexia, this may be related to its anti-inflammatory effect.

The phytochemical analysis of the extract confirmed the presence of several constituents previously isolated and identified from this crude drug. Arjunolic acid has been reported as an active compound reducing diabetic injury and other pathological conditions related to oxidative stress (Manna et al. 2009, Ghosh et al. 2010a, b). Furthermore, sitosterol and its glycosides have been shown to display anti-inflammatory and analgesic effect (Bouic et al. 1996, Yuk et al. 2007, Aragão et al. 2007, Messias et al. 2008). Other still unidentified constituents of the extract, including tannins, also contribute to the total activity of the crude drug. Tannins have been recognized as active and widespread compounds in several medicinal and food plants (Okuda 2005, Yoshida et al. 2000, 2005). The data presented here indicate that $C$. rubra extract possesses anti-inflammatory, antinociceptive and antipyretic effects and support to the traditional indication of $C$. rubra stem bark in inflammatory conditions.

\section{ACKNOWLEDGMENTS}

The authors are grateful to Superintendência do Desenvolvimento da Amazônia (SUDAM), Conselho Nacional de Desenvolvimento Científico e Tecnológico (CNPq), Fundação de Amparo à Pesquisa do Estado de Mato Grosso (FAPEMAT), Instituto Nacional de Ciência e Tecnologia em Áreas Úmidas (INAU) and Centro de Pesquisas do Pantanal (CPP) for the financial support. 


\section{RESUMO}

Cariniana rubra Miers (Lecythidaceae), popularmente conhecido como "jequitibá-vermelho", é uma árvore brasileira de grande porte, cuja casca é utilizada nas formas de infusão e decocção para o tratamento de condições inflamatórias. Os efeitos antiinflamatório, antinociceptivo e antipirético do extrato metanólico da casca do caule de Cariniana rubra (EMCr) foram avaliados em animais experimentais. A atividade antiinflamatória do EMCr foi testada nos modelos de edema de pata induzido por carragenina e dextrana em ratos, pleurisia induzida por carragenina em ratos e permeabilidade vascular aumentada por ácido acético em ratos. As atividades antinociceptiva e antipirética foram avaliadas utilizando os modelos de nocicepções induzidos por ácido acético e formalina, placa quente em camundongos e de pirexia, pela injeção de levedura de cerveja em ratos. O extrato inibiu o edema induzido por carragenina e dextrana, reduziu o volume de exsudato e a migração de leucócitos na pleurisia induzida por carragenina e o aumento da permeabilidade vascular induzida por ácido acético. $\mathrm{O} \mathrm{EMCr}$ inibiu a nocicepção nas contorções induzidas por ácido acético e na segunda fase do teste de formalina e diminuiu a temperatura retal. No entanto, foi inefetivo no teste da placa quente. A análise química por via úmida deu resultados positivos para saponinas, triterpenos, esteroides e compostos fenólicos. Fitosteróis e triterpenóides pentacícli$\cos (\beta$-sitosterol, estigmasterol, $\alpha$ and $\beta$-amirinas em mistura e ácido arjunólico) e as saponinas triterpenoidais: $3-O-\beta$-Dglucopiranosideo de sitosterol; ácido arjunólico 28 - $\beta$-glucopiranosila-23- $O$-acetila; ácido arjunólico 3- $O$ - $\beta$-glucopiranosila e ácido arjunólico 28- $O$-[ $\alpha$-L-rhamnopiranosil- $(1 \rightarrow 2)-\beta$-Dglucopiranosila]-23- $O$-acetila. Pode-se presumir que os efeitos do $\mathrm{EMCr}$ foram causados pela inibição da liberação e/ou ação de diversos mediadores inflamatórios. Estes resultados validam o uso tradicional das preparações caseiras de Cariniana rubra para tratar a inflamação.

Palavras-chave: antiinflamatório, antinociceptivo, antipirético, Cariniana rubra, Lecythidaceae, saponinas triterpênicas.

\section{REFERENCES}

AL-GHAMDI MS. 2001. The anti-inflammatory, analgesic and antipyretic activity of Nigella sativa. J Ethnopharmacol 76: 45-48.

Aragão GF, Cunha Pinheiro MC, Nogueira Bandeira P, Gomes Lemos TL AND De Barros Viana GS. 2007. Analgesic and anti-inflammatory activities of the isomeric mixture of alpha- and beta-amyrin from Protium heptaphyllum (Aubl.) march. J Herb Pharmacother 7(2): $31-47$.

Bouic PJd, Etsebeth S, Liebenberg RW, Albrecht CF, Pegel K and Van JaArsveld PP. 1996. Betasitosterol and beta-sitosterol glucoside stimulate human peripheral blood lymphocyte proliferation: Implications for their use as an immunomodulatory vitamin combination. Int J Immunopharmacol 18: 693-700.

CHAN GH AND FISCUS RR. 2004. Exaggerated production of nitric oxide (NO) and increases in inducible NO-synthase mRNA leves induced by the pro-inflammatory cytokine interleukin-beta in vascular smooth muscle cells of elderly rats. Exp Gerontol 39(3): 384-394.

De LA CRUz MG. 2008. Plantas Medicinais de Mato Grosso: a Farmacopéia Popular dos Raizeiros, Cuiabá: Carlini \& Caniato Eds, 224 p.

Di Paola R, Di Marco R, Mazzon E, Genovese T, Bendtzen K, Macri B, Nicoletti F And CuzzoCREA S. 2004. Prevention of carrageenan-induced pleurisy in mice by anti-CD30 ligand monoclonal antibody. Clin Immunol 113: 64-73.

Dinarello CA. 1989. The endogenous pyrogens in hostdefense interactions. Hosp Pract 24: 111-128.

EDDY NB AND LEIMBACH D. 1953. Synthetic analgesics II. Dithienylbutenyl and dithienylbutyl-amines. J Pharmacol Exp Ther 107: 385-393.

Ghosh J, Das J, Manna P And Sil PC. 2010a. Arjunolic acid, a triterpenoid saponin, prevents acetaminophen (APAP)-induced liver and hepatocyte injury via the inhibition of APAP bioactivation and JNK-mediated mitochondrial protection. Free Radical Bio Med 48: 535-553.

Ghosh J, Das J, Manna P And Sil PC. 2010b. Acetaminophen induced renal injury via oxidative stress and TNF- $\alpha$ production: Therapeutic potential of arjunolic acid. Toxicology 268: 8-18.

Harborne JB. 1998. Phytochemical Methods (A Guide to Modern Techniques of Plant Analysis), London: Chapman and Hall Ltd, $302 \mathrm{p}$.

HunskaAR S AND Hole K. 1987. The formalin test in mice: dissociation between inflammatory and non-inflammatory pain. Pain 30: 103-114.

KAUFMANN WE, ANDREASSON KL, ISAKSON PC AND WORLEY PF. 1997. Cyclooxygenases and the central nervous system. Prostaglandins 54: 601-624.

Koster R, Anderson M and De Beer EJ. 1959. Acetic acid for analgesic screening. Fed Proc 18: 412-414. 
Lima EF, SousA-Filho PT, BAstida J AND SCHMEDAHirschman G. 2002. Saponins from Cariniana rubra (Lecythidaceae). Bol Soc Chil Quim 47: 441-447.

Lo TN, Almeida AP And Beaven MA. 1982. Dextran and carrageenan evoke different inflammatory responses in rat with respect to composition of infiltrates and effect of indomethacin. J Pharmacol Exp Ther 221: 261-267.

Manna P, Sinha M AND Sil PC. 2009. Prophylactic role of arjunolic acid in response to streptozotocin mediated diabetic renal injury: Activation of polyol pathway and oxidative stress responsive signaling cascades. Chem-Biol Interact 181: 297-308.

MATOS FJA. 1988. Introdução à Fitoquímica Experimental, Fortaleza: Edições UFC, 128 p.

Meade CJ, Turner GA and Bateman PE. 1986. The role of polyphosphoinositides and their breakdown products in A23187-induced release of arachidonic acid from rabbit polymorphonuclear leucocytes. Biochem J 23: $425-436$.

Messias KLS, Campos-Buzzi F, Fischer LGO, MaLheiros A, Monache FD AND Cechinel-Filho V. 2008. Chemical composition and analgesic activity of the leaves and branches of Marlierea tomentosa Camb. Quim Nova 31(7): 1747-1749.

OKUDA T. 2005. Systematics and health effects of chemically distinct tannins in medicinal plants. Phytochemistry 66: 2012-2031.

Otuki MF, Lima FV, Malheiros A, Cechinel-Filho V, Monache FD, Yunes RA And CALixto JB. 2001. Evaluation of the antinociceptive action caused by ether fraction and a triterpene isolated from resin of Protium kleinii. Life Scie 69(19): 2225-2236.

PARRAT JR AND WEST GB. 1957. Inhibition by various substances of edema formation in the hind paw of the rat induced by 5 -hydroxytryptamine, histamine, dextran, egg white and compound 48/80. Brit J Pharm Chemot 13: $65-70$.

Ribeiro AR, VAle ML, Thomazzi SM, Paschoalato ABP, Poole S, Ferreira SH And Cunha FQ. 2000. Involvement of resident macrophages and mast cells in the writhing nociceptive response induced by zymosan and acetic acid in mice. Eur J Pharmacol 387: 111-118.
SEKIYA K, OKUDA H AND ARICHI S. 1982. Selective inhibition of platalet lipoxygenase by esculetin. Biochim Biophys Acta 713: 68-72.

SILVA MG, OLIVEIRA FS, QUINTANS-JÚNIOR LJ, THENIO OML AND DINIZ MFM. 2005. Investigação de efeito analgésico central e antiinflamatório de Conocliniopsis prasiifolia (DC) RM King and H Robinson em roedores. Acta Farm Bom 24(4): 533-537.

Vinegar R, TRuax JF, SElph JL, Lea A And Johnston PR. 1978. Quantitative "in vivo" studies of the acute actions of anti-inflammatory drugs in the rat. Eur J Rheumatol Infl 1: 204-211.

WhitTle BA. 1964. The use of changes in capillary permeability in mice to distinguish between narcotic and nonnarcotic analgesics. Brit J Pharmacol 22: 246-253.

Winter CA, Risley EA AND Nuss GW. 1962. Carrageenin-induced edema in hind paw of rat as an assay for anti-inflammatory drugs. P Soc Exp Biol Med 3: 544-547.

Yoshida T, Hatano T AND ITO H. 2005. High molecular weight plant poplyphenols (tannins): Prospective functions. Recent Adv Phytochem 39: 163-190.

Yoshida T, Hatano T, Ito H AND OKUdA T. 2000. Chemical and biological perspectives of ellagitannin oligomers from medicinal plants. Stud Nat Prod Chem 23: 395-453.

Yuk JE, Woo JS, Yun C-Y, LeE J-S, Kim J-H, Song G-Y, YANG EJ, HUR IK AND KIM IS. 2007. Effects of lactose- $\beta$-sitosterol and $\beta$-sitosterol on ovalbumin-induced lung inflammation in actively sensitized mice. Int Immunopharmacol 7: 1517-1527.

ZIMMERMANN M. 1983. Ethical guidelines for investigation of experimental pain in conscious animals. Pain 16(2): $109-110$ 